\title{
CONFLICTS AND ISLAH STRATEGY OF MUSLIM WOMEN ORGANIZATION \\ Case Study of 'Aisyiyah in Intra and Inter- Organizational Divergence
}

\section{Siti Syamsiyatun}

Sunan Kalijaga State Islamic University (UIN), Yogyakarta email:siti.syamsiyatun@uin-suka.ac.id

\section{Abstract}

Indonesians have witnessed the rise and fall of women organizations, at both micro and macro levels. In 1928, there were at least thirty women's organizations from various religious and regional backgrounds, and working on various issues, succeeded in holding the first Indonesian Women's Congress. But a century later there were only three organizations that survived, one of them is 'Aisyiyah. This current paper aims at exploring factors that contribute to the survival of the organization from a perspective of conflict resolution; it investigates what strategies they use to address intra and inter-organizational conflicts, by employing a qualitative analytical approach by way of case study. The data were collected through interviews and documentation. From studying several cases of organizational conflicts encountered by 'Aisyiyah at different times it is found that the organization constantly encounters intra and interorganizational conflicts. It applies various strategies to deal with them in accordance to the situation and necessity. What is pivotal is 'Aisyiyah's willingness to explore possibilities to find win-win solutions, such as silence, inaction, negotiation, mediation to conflict transformation, to find islah ways. However, when foundational values are at stake, 'Aisyiyah would not be reluctant to contend and use a strategy of threat.

[Bangsa Indonesia telah menjadi saksi bermunculan dan berjatubannya organisasi perempuan, baik tingkat nasional maupun lokal. Di tabun 1928 
terdapat kurang lebih 30 organisasi perempuan yang terlibat aktif dalam Kongres Perempuan Indonesia pertama. Namun seabad kemudian hanya tersisa tiga organisasi yang bertahan, salah satunya 'Aisyiyah. Dengan pendekatan resolusi konflik, artikel ini menjelaskan faktor dan strategi pendukung untuk bertahan menghadapi ketegangan internal dan eksternal organisasi. Data yang dikumpulkan melalui wawancara dan studi arsip menunjukekan bahwa 'Aisyiyah dalam beberapa periode yang berbeda telah menghadapipersoalan di dalam dan antar organisasi yang mana membutubkan strategi yang tepat dalam penyelesaiannya. Terpenting bagi 'Aisyiyah adalah usaha mencari solusi yang sama-sama menguntungkan menuju jalan damai seperti mendiamkan, negosiasi, mediasi bingga transformasi konflik. Namun jika nilai-nilai dasar organisasi menjadi taruhan, 'Aisyiyah tentu tak segan mengambil langkah tegas].

Keywords: 'Aisyiyah, conflict resolution, women organization, islah

\section{A. Introduction}

Indonesians commemorate Mother's Day on 22 December yearly. The selection of the date is to respect and sustain the high spirit of the first "Indonesian" Women Congress held on 22-25 December 1928, in Yogyakarta. The adoption and usage of the Indonesian language during the Congress only a few months after the historical Youth Pledge in October 1928 showed how women in the archipelago had positively supported the rise of Indonesian nationalism. ${ }^{1}$ Both events, the Youth Pledge and the Women Congress both held in 1928, become the catalyst for people organizing to cultivate their aspirations on nationhood, which took place long before the modern state of Indonesia declared its independence.

There were at least thirty women's organizations that sent their representatives to participate in the first Indonesian Women Congress of 1928, among others are 'Aisyiyah, Boedi Rini, Boedi Wanito, Darmo Laksmi, Karti Wara, Nahdlatul Fataat, Poetri Boedi Soedjati, Poetri

1 Susan Blackburn, Kongres Perempuan Pertama: Tinjauan Ulang, trans. by Koesalah Soebagyo Toer (Jakarta: Yayasan Obor Indonesia dan KITLV, 2007); Siti Syamsiyatun, "A Daughter in the Indonesian Muhammadiyah: Nasyiatul Aisyiyah Negotiates a New Status and Image", Journal of Islamic Studies, vol. 18, no. 1 (2007), pp. 69-94. 
Indonesia, Sarikat Islam Bagian Isteri, Wanito Katholiek, Wanito Oetomo, Wanito Sedjati, and Wanito Taman Siswa. From these participating women's organizations, only a few have survived until today, most notably are 'Aisyiyah, Wanito Taman Siswa, and Wanito Katholik. Little research has been done on these surviving organizations, despite the steady growth of the studies on Indonesian women organizations in recent decades. ${ }^{2}$ Most of these research deal with grand narratives of the organizations's historical course of their programmatic activities and survival. This current research is interested in investigating the more detailed accounts of how they strategize to survive, especially with regard to conflicts.

Many Indonesian women organizations, big and small, and of any kind, have broken, fell apart and ceased to operate due to unresolved conflicts or their failure to find common, satisfactory solutions. According to Darmiyanti Muchtar there were tens of new non-governmental organizations emerged in the decades of the 1980s to 2000s addressing issues mostly on gender, poverty, environment and reproductive health. However, due to various organizational conflicts, such as distribution of work and benefit, unclear expectation, and absence of sustainability strategies, these organizations split, fell apart and perish. ${ }^{3}$

In this paper, I would like to draw attention to an organization, which has been endured the trial of time and national politics, one of the initiators and contributors of the first Indonesian Women Congress 1928 which is not only still existing today, but also thriving, 'Aisyiyah. We believe that there is no single organization that experiences no conflict; on the contrary, an organization has always been encountered with constant conflicts, however, many have been unable to address adequately, that finally, they cease to operate, such as what has happened to most women

2 Sukanti Suryochondro, Organisasi-Organisasi Wanita di Indonesia (1975); Sukanti Suryochondro, Potret Pergerakan Wanita di Indonesia (Jakarta: Rajawali, 1984); Kuratul Aini, "Peranan Organisasi Wanita Taman Siswa dalam Pengembangan Pendidikan di Yogyakarta (1932 - 1946)", BA Thesis (Surakarta: Universitas Sebelas Maret, 2007); Ro'fah, “A Study of Aisyiyah: An Indonesian Women's Organization (1917-1998)", Master Thesis (Montreal: McGill University, 2000).

3 Darmiyanti Muchtar, "The Rise of the Indonesian Women's Movement in the New Order State”, Master Thesis (Murdoch: Murdoch University, 1999); Siti Syamsiyatun, Serving Young Indonesian Muslim Women: the Dynamics of the Gender Discourse in Nasyiatul Aisyiyah 1965-2005 (Saarbrücken: Lambert Academic Publsihing, 2010). 
organizations participating in the first Women Congress. Thus, what is interesting is the strategies 'Aisyiyah has employed to deal with these conflicts so it remains intact and even grows.

As a large membership-based Muslim women organization in Indonesia, 'Aisyiyah has proven to pass different trials of intra and interorganizational conflicts as well as social changes and dynamics at large in the archipelago. 'Aisyiyah remains intact when it celebrated its centennial anniversary in 2017 if we are using the Common Era calculation. Such achievements have attracted few scholars to do research on 'Aisyiyah such as mentioned previously. What I see as lacking in the research is 'Aisyiyah's little narratives on organizational conflicts it has encountered and how the women deal with these various conflicts as they organize a day in, day out.

It is intriguing to know and to dig out deeper how the women of 'Aisyiyah at different times, from Dutch Colonial era to present Indonesia in Yogyakarta have dealt with different kinds of organizational conflicts, intra and inter, so that the organization remains united, and thrives. What are the sorts of organizational conflicts 'Aisyiyah have encountered; what are the examples of strategies they have applied, and what are the outcomes of such a strategy? By researching their voiced strategy I wish to strengthen social and scholarly recognition for women's voices and experiences are a valid source of knowledge, that need to be nurtured further. $^{4}$

Why is it important to case study the strategy of 'Aisyiyah in addressing organizational conflicts? There could be a very long list of arguments; however, I would like to limit in arguing the significance of research from the point of view of social impacts of 'Aisyiyah's organizational behavior in maintaining social cohesion of the Indonesian community. Firstly, is the fact that it is very research on actual behavior of women's organizations in dealing with conflicts, thus we have no

${ }^{4}$ Nina Nurmila, “The Indonesian Muslim Feminist Reinterpretation of Inheritance", in Islam in Indonesia: Contrasting Images and Interpretations, ed. by Jajat Burhanudin and Kees van Dijk (Amsterdam: Amsterdam University Press, 2013), pp. 109-22; P.A. van Doorn-Harder, "Controlling the Body: Muslim Feminists Debating Women's Rights in Indonesia”, Religion Compass, vol. 2, no. 6 (2008), pp. 1021-43; Saskia Wieringa, "IBU or the Beast: Gender Interests in Two Indonesian Women's Organizations”, Feminist Review, no. 41 (1992), pp. 98-113. 
adequate understanding and knowledge about Muslim women's strategies in sustaining their organization from a perspective of conflict resolution.

Secondly, 'Aisyiyah has very large memberships across the nation. It is assumed that its organizational decisions, standpoint on issues, as well as its actual behavior have impacted not only to members of the organization, the Indonesian Muslim women, but also to men, and families and their stakeholders, at least. Thirdly is 'Aisyiyah's ability to remain intact, united as an organization from colonial time to the present day. This fact shows that the members of the organization have learned and developed skills to address challenges, one of which is conflicts.

Fourthly, 'Aisyiyah is among the few organizations participating actively in the first Indonesian Women Congress in 22-25 December 1928 that still exist and thrive. These four sociological facts, in my view, find their significance in our today's Indonesia. In the past years, Indonesian communities have been bombarded with extreme political information and exhortation that tend to polarize our communities to the extent that endanger our social unity or cohesion as a nation. There are few researches on the roles of women in conflict resolution, however, most of the studies have been on personal and non-organizational representation, ${ }^{5}$ so this present research would contribute in filling the gap on the strategies taken by women on an organizational basis. It is expected that this research will contribute to supply not only theoretical knowledge in conflict resolution or transformation, but also to provide a variety of practical tools that can be applied in organizational settings.

My current research on 'Aisyiyah adopts a descriptive qualitative design by doing a case study in which I prefer to focus on the depth of arguments presented in specific conflictual cases rather than on the vast number of conflicts encountered by 'Aisyiyah, as suggested by Lexy J.

5 Dahlia Lubis, "Peran Muslimah dalam Penyelesaian Konflik", TEOSOFI: Jurnal Tasawnf dan Pemikiran Islam, vol. 5, no. 2 (2015), pp. 486-512; Anna Christi Suwardi, "Peran Gerakan Perempuan dalam Reintegrasi Perempuan Eks-Kombatan Pasca Konflik: Studi Atas Liga Inong Aceh (LINA)", Jurnal Hubungan Internasional, vol. 4, no. 1 (2015), pp. 12-22; "Peran Perempuan dalam Penyelesaian Konflik Kurang Diakui”, KOMPAS. com (24 Mar 2010), https:/ / nasional.kompas.com/read/2010/03/24/16383094/Peran. Perempuan.dalam.Penyelesaian.Konflik.Kurang.Diakui..., accessed 10 Oct 2020. 
Moleong and Cresswell and Poth in case study inquiry. ${ }^{6}$ In this case, I select a few organizational conflicts experienced by 'Aisyiyah and analyze them. Due to the complexity of 'Aisyiyah's conflictual dimensions and experiences, I would like to limit my research by selecting few conflicts addressed by 'Aisyiyah leaders and members in a different time, from late colonial era up to present day, and those experienced at different levels of leadership.

Presently, 'Aisyiyah has been operating in 34 provinces throughout Indonesia, as well as abroad, such as in Australia, Egypt, Hong Kong, Malaysia, and Taiwan. In this research, I gather the data from selected informants through interviews, observations, and documentation techniques. I interviewed fifteen (15) willing 'Aisyiyah leaders and members, current and past, who have been active in different levels of leadership, from national to local levels. All informants' names mentioned in this article are pseudo names. I also observed a number of 'Aisyiyah meetings or gatherings in which there have been organizational conflicts in addressing certain issues or problems. One of the limitations of my research is that all the meetings I observed and all informants I interviewed have lived in Java, so it cannot be avoided that the findings show Javanese tendencies. In addition, I also refer to few documents produced by 'Aisyiyah or other agencies in particular from which I gather data on what have been reported on conflicting interests and issues. The research also employs an organizational perspective in the sense that my unit of analysis is organization as represented in individuals, which means the interests, the values, the needs, the positions expressed or argued by women informants as representative of 'Aisyiyah organization, not their personal wish. Most data were collected from November 2019-March 2020, with few interviews have been recorded in the past years.

In discussing the issues of conflicts and strategies employed by 'Aisyiyah, I adapt a few theories on organizational conflicts ${ }^{7}$ as well as

${ }^{6}$ Lexy J. Moleong, Metodologi Penelitian Kualitatif, 38th edition (Bandung: PT Remaja Rosdakarya, 2018); John W. Creswell, Qualitative Inquiry \& Research Design: Choosing among Five Approaches, 4th edition (Los Angeles: SAGE, 2018).

Atif Chaudhry and Ch Asif, "Organizational Conflict and Conflict Management: a Synthesis of Literature", Journal of Business and Management Research, vol. 9 (2015), pp. 238-44; Dean Pruitt, Jeffrey Rubin, and Sung Hee Kim, Social Conflict: Escalation, Stalemate, and Settlement, 3rd edition (Boston: McGraw-Hill Education, 2003). 
conflict transformation, ${ }^{8}$ and islab theory from a Qur'anic perspective. ${ }^{9}$ These theories will also guide me in creating some sorts of hypotheses that organizations which are able to resolve their organizational conflicts and transform them into their positive modalities have greater possibility to survive and thrive, and vice versa.

Conflicts have been operating since the human creation and will remain to exist as far as human's existence. Qur'an narrates us examples of conflicts encountered by our common ancestors, Adam and Eve, and their children until today, when we find so many justice courts are erected to adjudicate conflicting parties. It is therefore nonsense to hope that we will not face any conflicts in our lifetime. What is certainly more plausible is to learn how to address, respond, resolve or to transform the conflicts we are facing, so that they will not make things we care about become deteriorating, at least. The best we want to achieve is knowing the ways to address the conflicts so that they might transform things for the betterment of our common good.

During our lifetime we have seen many conflicts occurred between different agents, from individuals to groups, even different nationalities. Members of a family, for instance, father, mother, children, do have experiences of conflicts arising from different points of view on things as simple as preference of TV channels, tastes of food, destinations of family holidays, to more complex issues such as choosing schools or life partners. Groups or organizations also encounter conflicts in their daily routines. Some conflicts are successfully resolved, while others are not, and that could and have led to organizational crisis, fragmented, or even extinction, such as what we have seen in past wars and crisis, for instances in the case of the holocaust, genocide in Serbs, as well as recent

8 John Paul Lederach, The Little Book of Conflict Transformation (Vancouver, B.C: Langara College, 2016); Christine Mattl, "John Paul Lederach; The Little Book of Conflict Transformation”, Perspektive Mediation, vol. 5, no. 4 (2008), p. 222.

${ }^{9}$ Saipul Hamdi, "Politik Islah: Re-Negosiasi Islah, Konflik, dan Kekuasaan dalam Nahdlatul Wathan di Lombok Timur”, Jurnal Kawistara, vol. 1, no. 1 (2011), pp. 1-14; Hannan Putra, "Ensiklopedi Hukum Islam: Islah (1)", Republika Online (23 Nov 2012), https://republika.co.id/berita/dunia-islam/khazanah/12/11/23/mdxhpd-ensiklopedihukum-islam-islah-1, accessed 25 May 2020; Fikri, "Transformasi Nilai Al-Islah terhadap Keberagaman Konflik: Epistemologi Hukum Islam dalam Al-Qur'an”, Al-Risalah, vol. 16, no. 02 (2018), pp. 201-16. 
human crisis in Rohingnya, Myanmar. The sources of conflicts faced by organizations have been so varied, and so are the strategies they have taken to deal and address the conflicts. This is because the impacts of conflicts are so varied just as various as their causes; some have a light impact, such as expressed disagreement that can be negotiated after moments, ${ }^{10}$ while others could be destructive and catastrophic such as those that lead to prolonged crisis and wars.

In this research, I refer to organizational conflict as a state of discordance caused by the actual or perceived differences of ethical values, needs, and interests between people or members working together. ${ }^{11}$ These people who are working together can be in the same organization or in different organizations that seek together to achieve some common goals. In this sense, organizational conflicts may occur in intra-organizational or inter-organizational contexts. Conflict could manifest in many forms in organizations. From the point of view of the subjects, there are the inevitable differences amongst members, between members and formal leaders, and with those people entrusted with leadership. In a largescale membership-based organization, like 'Aisyiyah, these subjective conflicts could be seen taking place in different places and levels of organizational structures. There are disputes over how organizational funds and resources should be collected and distributed, how the work and task should be done, and how and in what ways such work should be accomplished. There are sometimes jurisdictional disagreements among individuals, departments, and between unions and management. There are subtler forms of conflict involving rivalries, jealousies, personality clashes, role definitions, and struggles for power and favor.

People in organizations have shown different responses to different conflicts they have encountered. According to a research conducted by AMAN, women tends to employ informal forum and informal strategy to talk about the conflicts, such through daily activities of selling and

10 Examples of these are found in daily routines of organizational relations, where members show differing opinions on issues, and finally are able to find common solutions. Observation on a number of 'Aisyiyah meetings in Yogyakarta on 27 January 2020. Same opinion also expressed by Mrs. Nordji, interview (10 Sep 2020).

11 Chaudhry and Asif, "Organizational Conflict and Conflict Management", pp. 238-44; M. Afzalur Rahim, "Toward a Theory of Managing Organizational Conflict", International Journal of Conflict Management, vol. 13, no. 3 (2003), pp. 206-35. 
buying. ${ }^{12}$ Some of the most frequently applied strategies to resolve organizational conflicts are avoidance, competition, accommodation, compromise, and collaboration between the representatives of some combination of individuals and/or groups in response to interpersonal conflict, intergroup conflict, or conflict between an organization and one or more of its stakeholders. ${ }^{13}$

In its general term conflict is disagreement on a certain issue in which oneself or people do not have the same opinion, expectation. Many scholars consider conflicts under certain situation and condition as acceptable, even necessary for understanding various standpoints, new ideas for moving forward; without differing ideas an organization will be stagnant. ${ }^{14}$ Despite the benefit of conflicts, most classical theories in an organization perceived conflicts as something undesirable that must be eliminated, at least be resolved or transformed. John Paul Lederach argued that repeated conflicts are signs of deeper social, systemic problem; therefore, they need special way to address. In order to provide an upstream solution to repeated conflicts Lederach proposes a concept of conflicts transformation is to envision and respond to the ebb and flow of social conflict as life-giving opportunities for creating constructive change processes that reduce violence, increase justice in direct interaction and social structures, and respond to real-life problems in human relationships. ${ }^{15}$

Because 'Aisyiyah has a deep loyalty to Islamic values in running the organization, I assume that the way the 'Aisyiyah women respond to conflictual situations has some reference to Qur'anic tradition. For this

12 Sentiela Ocktaviana, Widjajanti M. Santoso, and Dwi Purwoko, "Peran-Peran Perempuan di Wilayah Konflik: Antara Korban, Penyintas, dan Agen Perdamaian”, Jurnal Masyarakat dan Budaya, vol. 16, no. 3 (2014), pp. 383-98; Suwardi, "Peran Gerakan Perempuan dalam Reintegrasi Perempuan Eks-Kombatan Pasca Konflik"; Lubis, "Peran Muslimah dalam Penyelesaian Konflik".

13 Rahim, "Toward a Theory of Managing Organizational Conflict"; Syamsu Rizal Panggabean et al., Policing Religious Conflicts in Indonesia, trans. by Natalia Laskowska (Jakarta: Center for the Study of Religion and Democracy, Paramadina Foundation, 2015).

\footnotetext{
14 Rahim, "Toward a Theory of Managing Organizational Conflict".

15 Lederach, The Little Book of Conflict Transformation.
} 
reason, I also employ islah theory conceptualized by Saiful Hamdi. ${ }^{16}$ Islah in Arabic means to repair, reconcile, and eliminate disputes or damage. It may take in different forms of actions or activities, such as efforts to create peace, to bring harmony, to facilitate people to make peace with one another, to do good deeds that lead to a better life. ${ }^{17}$

The diverse meanings of islah is showed in the Qur'an; so islah can be applied in different contexts and purposes. ${ }^{18}$ The followings are various meaning of islah mentioned in the Qur'an, namely in Qur'an 2: 220 and 228, Qur'an 4: 35 and 113, Qur'an 11: 87, and Qur'an 7: 55 and 85. It is believed that the Qur'an has commanded to human being to uphold islah, thus it is a kind of obligation for all Muslims to keep islah, both personally and socially. For instance, in Qur'an 4: 35 Allah SWT ordered the disputing husband and wife, to find islab by sending a third party (bakam) from the husband and wife sides to reconcile them.

In short, in analyzing the data on cases of 'Aisyiyah's conflicts I adopt a framework that combines few theories on conflicts and islab from Qur'anic perspective, as well as of conflict transformation developed by well-known scholars in these fields, such as Dean G. Pruitt and John Paul Lederach.

\section{B. Historical Overview of 'Aisyiyah's Engagements with Womanhood}

In presenting the results of my research and analyzing them I divide this section into sub-sections. First I describe the brief history of 'Aisyiyah in order to provide better pictures of some of the challenges encountered by the organization. Second, I present cases of organizational conflicts and the strategies taken by 'Aisyiyah in different times and different issues.

Women organizations have been important agents in developing and maintaining Indonesian nationalism. Long before the proclamation of the independence of the Republic of Indonesia as a nation-state in 1945, women organizations have declared their support for the cultivation of Indonesian nationhood during their first congress on 22-25 December 1928 , in Yogyakarta. This congress was organized just about two months

16 Hamdi, "Politik Islah".

17 Putra, "Ensiklopedi Hukum Islam".

18 Fikri, "Transformasi Nilai Al-Islah terhadap Keberagaman Konflik". 
after the second Youth Pledge (Sumpah Pemuda) on 28 October 1928, in which young people from islands of the archipelago declared an oath of becoming one country (home land-water), nation, and one language: Indonesia. The strong supports of women organizations' can be seen, for example, in the usage of Indonesian language, in their proposal of improving education for girls, regulating the marriage, and encouraging women's involvement in socio-political concerns.

Thirty (30) organizations participated in the said Women Congress in December 1928. These 30 women organizations were mostly local, cultural-based, while others were ideal-political based and a religiousbased. 'Aisyiyah was considered to be religious-based (Islam) organization. Hence as expected, there were a lot of differences of perspectives, of interests, of values expressed by these organizations, and many ways of resolving conflicts were being taken that during the congress. Despite such conflicting interests, values and needs these women organizations showed a willingness to work for the betterment of girls, women, and family life in particular through various ways they could agree with one another. ${ }^{19}$

The first Women Congress featured fifteen (15) selected speakers, two of which were representative from 'Aisyiyah, they were Siti Moendijah and Siti Hajinah. Along with other organizations, 'Aisyiyah members had been active in the first women congress, as speakers, as organizing committee and active participants. In fact, 'Aisyiyah's presence in the congress has impressed Rangkajo Chairoel Sjamsoe Datoek Toemenggoeng (henceforth shortened with Mrs. Toemenggoeng), an assigned reporter of van der Plas. Mrs. Toemenggoeng in her report wrote that many 'Aisyiyah members participated in the Congress, these can be seen from their special attire of kerudung (long head covering). Even on the second day of the Congress girls or daughters of 'Aisyiyah performed welcoming songs in Indonesian and Arabic. ${ }^{20}$

Historically, 'Aisyiyah was inaugurated on May 19, 1917, in Yogyakarta, in a grand event that coincided with the celebration of the anniversary of the Isra' Mirraj of the Prophet Muhammad, and the gathering of Muhammadiyah. Before it was formally adopted the name

19 Blackburn, Kongres Perempuan Pertama.

20 Ibid. 
'Aisyiyah, the organization had evolved from Muslim women learning circle called Sapa Tresna (Those who love [to learn]) started in 1914, just after Muhammadiyah, founded in 1912, began to open its schools and educational facilities for women and girls. ${ }^{21}$ During the inauguration of the new name of the organization 'Aisyiyah, nine women were chosen as the leaders, and a young woman named Siti Bariyah was given the mandate as the first Chair of 'Aisyiyah.

The history of 'Aisyiyah, then Sapa Tresna, cannot be separated from the history of Muhammadiyah, one of the largest, long-standing Muslim organizations in Indonesia. The development and spread of 'Aisyiyah to places and regions outside Yogyakarta have been in accord with the pattern of Muhammadiyah. ${ }^{22}$ Such pattern is actually found also during the early development of 'Aisyiyah, whereby most of 'Aisyiyah members have been family members of Muhammadiyah members: their wives, daughters, mothers, aunties or workers and supporters. When Muhammadiyah flourishes into areas outside Java, 'Aisyiyah follows. ${ }^{23}$

There were debates and conflicts over the change of name actually; women from outside Java had demanded the name of the organization should not be Java-centric, Sapa Tresna. During the national meeting of Muhammadiyah, in which women of Sapa Tresna also participated, they expressed that the name of Sapa Tresna should be changed to adopt the new reality that members have come from different parts of the archipelago. ${ }^{24}$ Further discussion on this organizational conflict on naming is provided in the next sub-section.

Beginning from a learning group of young Muslim women, Sapa Tresna, now the organization known as 'Aisyiyah, a nation-wide organization, with millions of members, supporters, cheerleaders

21 PP 'Aisyiyah, Sejarah Pertumbuhan dan Perkembangan 'Aisyiyah (Yogyakarta: Pimpinan Pusat 'Aisyiyah: Seksie Khusus Penerbitan dan Publikasi, 1992); Ro'fah, “A Study of Aisyiyah".

22 Mrs. Ismah, interview (19 Nov 2020); Mrs. Norkam, interview (19 Nov 2020).

23 Mitsuo Nakamura, The Crescent Arises over the Banyan Tree: A Study of the Muhammadiyah Movement in a Central Javanese Town, c.1910s-2010, 2nd edition (Singapore: Institute of Southeast Asian Studies, 2012); Syamsiyatun, "A Daughter in the Indonesian Muhammadiyah".

24 Sejarah 'Aisyiyah, http://www.aisyiyah.or.id/id/page/sejarah.html, accessed 11 Sep 2020. 
(penggembira), and interested people. Normatively, all of 'Aisyiyah missions, programs and activities have been motivated to apply an ethical mandate of amar ma'ruf nabi munkar (enjoining what is good/wise, and forbidding what is bad/destructive) to create a civil society. ${ }^{25}$ Women organizing in 'Aisyiyah are expected to adopt a kind of religious, spiritual motivation. ${ }^{26}$

In practice, however, we find many different reasons of women joining 'Aisyiyah: from being unconsciously educated within the organization circle to an individual quest to find suitable, satisfying women's movement. ${ }^{27} \mathrm{Few}$ members of 'Aisyiyah had stated what makes them love joining 'Aisyiyah. Ummul Baroroh, a member from Semarang who is also a faculty at the State Islamic University Walisongo said that she choose 'Aisyiyah because the organization is relatively independent in managing its programs, does not depend on the government's money or support, and the organization is for everyone without border in educational level or wealth. Islamiyaturrahmah, a faculty at Universitas 'Aisyiyah Yogyakarta, mentioned that she feels tranquil by being active in 'Aisyiyah, it also means serving God by serving humanity and its surrounding as a preparation for life in Here After. ${ }^{28}$ Alimatul Qibtiyah, a faculty at the State Islamic University Sunan Kalijaga Yogyakarta, also a Commissioner at the National Commission on Women, confessed that she joins 'Aisyiyah because she finds that it is suitable to her quest and vision of progressive womanhood. ${ }^{29}$

Technically, the implementation of 'Aisyiyah ethical mandate is carried out through a number of charitable endeavors, programs, and

25 Mrs. Mudayati, a local leader of 'Aisyiyah, interview (30 Nov 2019).

26 Muhammad Ghazali Bagus Ani Putra, Perempuan-Perempuan Pemburu Surga: Menyibak Rahasia Kejayaan 'Aisyiyah (Yogyakarta: Suara Muhammadiyah, 2017); Pieternella van Doorn-Harder, Women Shaping Islam: Reading the Qu'ran in Indonesia (Urbana: University of Illinois Press, 2010).

27 Mrs. Amqi, interview (17 Nov 2019); Mrs. Witra, interview (17 Nov 2019); Mrs. Noorka, interview (17 Nov 2019); Mrs. Isroh, interview (17 Nov 2019).

28 Islamiyaturrahmah, interview (18 Nov 2019).

29 Siti Syamsiyatun, “Aisyiyah Women: The Messages of Sidang Tanwir”, IBTimes.ID (18 Nov 2019), https:/ /ibtimes.id/aisyiyah-women-the-messages-of-sidangtanwir/, accessed 9 Sep 2020. 
activities, including: ${ }^{30}$

- Instilling faith, deepening and broadening understanding, increasing practice and disseminating Islamic teachings in all aspects of life.

- Increasing the dignity of women in accordance with Islamic teachings.

- Improving the quality and quantity of studies/learning of Islamic teachings.

- Strengthening faith, encouraging sincere worship, and enhancing noble character.

- Increasing the spirituality, jihad, zakat, infaq, shodaqoh, endowments, grants, building and maintaining places of worship, and other business charities.

- Fostering the young Muhammadiyah girls to become the pioneers, executors, and refiners of 'Aisyiyah's endeavors.

- Improving education, developing culture, expanding science and technology, and stimulating research.

- Advancing the economy and entrepreneurship towards improving quality of life.

- Improving and developing activities in social fields, community welfare, health, and the environment.

- Improving and striving for law enforcement, justice, and truth, and fostering a spirit of national unity.

- Improving communication, ukhuwah/sisterhood, cooperation in various fields and communities both at home and abroad.

- Other businesses that are in accordance with the aims and objectives of the organization.

'Aisyiyah pioneered in the founding of education for children, boys and girls, in Indonesia, called Taman Kanak-Kanak 'Aisyiyah Bustanul Athfal (TK ABA). It began to provide early childhood education service in 1919, and today the TK ABA owned by 'Aisyiyah amounted to more than 19.000 throughout Indonesia. ${ }^{31}$ It also launched the eradication

30 Identitas, Visi, dan Misi 'Aisyiyah, http:/ / www.aisyiyah.or.id/id/page/identitasvisi-dan-misi.html, accessed 14 Feb 2020.

31 Tutin Aryanti, "Shame and Borders: The 'Aisyiyah's Struggle for Muslim Women's Education in Indonesia", in Gender, Religion and Education in a Chaotic Postmodern World, ed. by Zehavit Gross, Lynn Davies, and Al-Khansaa Diab (Dordrecht: Springer Netherlands, 2013), pp. 83-92. 
of illiteracy both Latin alphabet illiteracy and Arabic illiteracy in the beginning, provided religious education for batik workers, married and young women who were denied education during the colonial era. 'Aisyiyah was the first Muslim women to establish a womenss mosque in Yogyakarta in1922, from which women learn how to manage a house of worship and its connecting program activities. The enactment of women's house of worship or mosque was then replicated by 'Aisyiyah members in other parts of Indonesia.

Improving literacy has been one of 'Aisyiyah's outstanding program since its establishment until today; from creating basic learning facilities to combat alphabetical illiteracy in the beginning, to promoting scientific, media, cultural literacy through various schools up to university/higher education. UNISA or Universitas 'Aisyiyah Yogyakarta is considered the first higher education to be founded by a women's organization, and now few more 'Aisyiyah universities in a number of cities are in the queue for launching. ${ }^{32}$ Literacy has also been advanced through non formal tracts, which are through women's writing groups and training to manage national magazine Suara 'Aisyiyah-first issued in 1926 and continues to publish until today. ${ }^{33}$

To advance womens participation in the economy, until September 2020, 'Aisyiyah has established 568 cooperatives for women and empowered the family economy through 1426 Family Economic Business Development (BUEKA shortened version of Badan Usaha Ekonomi Keluarga 'Aisyiyah), as well as fostered women's home industry. Furthermore, 'Aisyiyah has contributed significantly in promoting the health of the nation, especially women and children. Since the Dutch Colonial era, 'Aisyiyah has been establishing maternity clinics, clinics for mothers and children, and later it also founds general hospitals. In September 2020 'Aisyiyah have managed about 15 general hospitals, 64 maternal clinics, 7 mother and child hospitals, 27 medical centers (Balai Pengobatan), 20 Balkesmas (Balai Kesehatan Masyarakat), 44 BKIA (Balai

32 Mrs. Hasti, interview (19 Nov 2019).

33 Tika Ramadhini and David Kloos, "Visualizing Female Islamic Leadership in Indonesia: Suara Aisyiyah and Amanah", in Voyage of Discovery: Exploring the Collections of the Asian Library at Leiden University, ed. by Alexander Reeuwijk (Leiden: Leiden University Press, 2017); Sejarah 'Aisyiyah; 'Tentang|Majalah Suara 'Aisyiyah', Suara Aisyiyah, https:/ / suaraaisyiyah.id/tentang/, accessed 11 Nov 2020. 
Kesehatan Ibu dan Anak), and 105 integrated services post (Posyandu-pos pelayanan terpadu) spread throughout Indonesia. 'Aisyiyah's contribution in the field of social welfare manifested in the form of the establishment of orphanages, elderly home (griya lansia), work training centers, and assistance for poor children and the elderly in the community have been continuing since the past decades. ${ }^{34}$

Managing such various social services and entrepreneurship is not an easy task, however, 'Aisyiyah has been able to do so by creating regulations that have to be respected by all members and stakeholders involved. Are these regulations agreed and approved easily without any conflicts? Certainly not, there are so many conflicts involved, and so many strategies are applied. Some have worked better than the other, some event failed that need to be addressed by different strategies. Undoubtedly, I cannot cover all kinds of organizational conflicts encountered by 'Aisyiyah in this paper, however, I will select few examples of organizational conflicts as well as the strategies taken by 'Aisyiyah to address the issues, and analyze them using the theories I propose in the aforementioned section.

\section{C. 'Aisyiyah Strategies in Addressing Organizational Conflicts}

In this section, I would like to present few cases of organizational conflicts encountered by 'Aisyiyah in one during the Dutch Colonial era, one during the Old Order and few examples from recent years for different cases. The cases from previous decades are significant to be highlighted here, because they set examples and reference for later generations of 'Aisyiyah on how to respond to intra and inter-organizational conflicts. My research confirms this attitudinal and behavioral heritage from the past. I provide analyses how these conflicts were resolved, and some of them even transformed. The selection of these cases of organizational conflicts based on considerations that they are pivotal not only to the sustainability of 'Aisyiyah, but also to lay foundational practices in conflict

34 "Pimpinan dan Amal Usaha Seluruh Indonesia", wmw.aisyiyah.or.id, http:// www.aisyiyah.or.id/en/page/amal-usaha.html, accessed 11 Sep 2020; Suryan Widati, Iwan Triyuwono, and Eko Ganis Sukoharsono, "Wujud, Makna dan Akuntabilitas 'Amal Usaha' sebagai Aset Ekonomi Organisasi Religius Feminis”, Jurnal Akuntansi Multiparadigma, vol. 2, no. 3 (2011), pp. 369-80. 
resolution and transformation for future 'Aisyiyah. These examples prove that if 'Aisyiyah would survive it cannot avoid conflicts, but to nurture the capacity to exercise various strategies of addressing the conflicts.

\section{Analysis of Case Intra-organizational Conflict on Naming}

The first case is about changing the name, from Sapa Tresna into 'Aisyiyah, which occurred in the Dutch Colonial era in Yogyakarta. As narrated in previous sub-chapter, the name of Sapa Tresna was considered Java-Centric and no longer representing the reality of women participating in the organization that by then in 1917 already came from different parts of the archipelago. ${ }^{35}$

During a meeting of Muhammadiyah, in which its women members also present, Sapa Tresna and Muhammadiyah leaders discussed about the proposal of a new name for the organization. There were proposals of new names with Malay-rooted and Arabic rooted names, and names of the family of the Prophet Muhammad, such as Siti Khadijah and Fathimah. According to Adaby Darban, Muhammadiyah dan Sapa Tresna leaders involved intensively in the debate, because a name is important for them. ${ }^{36}$ For example, Muhammadiyah was chosen by male groups to name their organization because Kiai Ahmad Dahlan and his companions have envisioned that the organization should respect and uphold the moral teachings of Prophet Muhammad, so the organization was maned Muhammadiyah, follower or those who take the ways of Muhammad. With regard to the proposal of name change of Sapa Tresna for the women's group, members of Muhammadiyah, as the supervisors at that time, were also involved in the discussion along with the women.

After much discussion, a Muhammadiyah leader, named Kiai Fachrodin proposes a name of 'Aisyiyah, which means the follower of 'Aisyiyah, one of the wives of the Prophet. In this case, members of Sapa Tresna invited a third person, a mediator, in this case Kiai Fachrodin, to mediate the conflicts of proposals of new names, if we are looking at

35 Interview with Mrs. Chamna, and Mrs. Elman, both members of Central Board of "Aisyiyah in the past, 19 November 2014.

36 Sejarah 'Aisyiyah; "Siapakah Pengusul Nama Organisasi 'Aisyiyah?”, IBTimes. ID (27 Feb 2020), https://ibtimes.id/siapakah-pengusul-nama-organisasi-aisyiyah/, accessed 28 Feb 2020; Syamsiyatun, Serving Young Indonesian Muslim Women: 
the phenomenon using Pritt's theory. ${ }^{37}$ It is clear from the document that members of Sapa Tresna accepted the proposal by the mediator. The name of 'Aisyiyah does serve their purposes and spirit, and it is beyond their cultural tights, and it is more universalistic from an Islamic history point of view. 'Aisyiyah means the way or follower of 'Aisyah, one of the beloved wives of prophet Muhammad.

Female members from Java and outside Java considered the proposed name as adequate, does not contain cultural primordialism, and it has root in common Islamic history and ethics, thus they agree to change the name of their organization from Sapa Tresna into 'Aisyiyah. The women have been able to maintain unity and peaceful relationships between Java-based members and non-Java-based ones. Such actions can be categorized to seek and practice islab if we refer to Saiful Hamdi's and Fikri's theory on islab. ${ }^{38}$ The imagery character of 'Aisyah was chosen because the Muslim women of Sapa Tresna thought that she had exhibited characters that serve best the idea of womanhood imagined by them. 'Aisyah, the wife of the Prophet Muhammad was well-known for her sincerity, faithfulness, loving, and vast knowledge. It was narrated that after the death of the Prophet many of his companions seek advice and religious knowledge from 'Aisyah."

We could not exactly know the extent of the conflicts as there is no well-written report on that; however, the resolution of organizational conflict through negotiation and deliberation seemed to be well accepted. The non-Javanese members on the one hand had proposed that the name of Sapa Tresna be changed, and the Javanese women, founders, and first members of the organizations, on the one hand, apparently had acted wisely, and reduced their expectation of defending the original Javanese

37 Mattl, "John Paul Lederach; The Little Book of Conflict Transformation"; Dean G. Pruitt and Douglas F. Johnson, "Mediation as an Aid to Face Saving in Negotiation", Journal of Personality and Social Psychology, vol. 14, no. 3 (1970), pp. 239-46; Dean Pruitt, Communication Chains in Negotiation Between Organizations, Occasional Papers, no. 3 (Istanbul: Sabanc1 Universitesi, 2003).

38 Hamdi, "Politik Islah"; Fikri, "Transformasi Nilai Al-Islah terhadap Keberagaman Konflik". 2000).

39 Nabia Abbott, Aishab: the Beloved of Mohammed (North Stratford, NH: Ayer, 
name for the sake of the unity and sustainability of the organization. ${ }^{40}$ In fact, by adopting a new name, the organization's Islamic identity grew stronger, as well as getting greater supports and popularity from nonJavanese women. The willingness to do negotiation and deliberations shown by Muhammadiyah and 'Aisyiyah members from different places signified that the spirit of islah, to create peace, to accord to an agreement has been implemented and become a source of reference for conflicts resolution in 'Aisyiyah circle.

The new name of the organization, 'Aisyiyah, clearly had satisfied most members because all and everyone has felt connected with the personage of 'Aisyah, and it represents their common identity as Muslims. We can say that a conflict over the name of an organization is not an easy one to resolve because the name can represent many things; represent the organization's identity, value, purposes, and interests. ${ }^{41}$ The fact that women of Sapa Tresna, then became 'Aisyiyah can resolve and find their common values and aspirations, is a significant achievement why is it significant?. It turns out that the profile, the noble character of the wife of the Prophet Muhammad, 'Aisyah, keeps inspiring later women who become members of 'Aisyiyah. In the case of finding a new name, if I borrow the theory of John Paul Lederach, I argue that 'Aisyiyah women had transformed the potential different aspirations of women, or at least had been successful in making negotiation that resulted in an agreement for long term common good of the organization, and set aside their primordial affiliations of cultural and local backgrounds.

During the early twentieth century, the archipelago was home to tens of kingdoms and sultanates. Local cultural identity was still very strong, so we could assume that each specific local culture would have proposed a name or alternative names that were closely related to their cultural imaginations. However, these women of Sapa Tresna especially had been able to envision new Muslim womanhood that transcended local imagery of womanhood. The new progressive Muslim womanhood has

40 "Siapakah Pengusul Nama Organisasi Aisyiyah?”; Mrs. Chamna, interview (19 Nov 2014); Mrs. Nordji, interview (10 Nov 2020).

41 Siti Ruhaini Dzuhayatin, "Dinamika Ideologisasi Gender dalam Keputusan Resmi Muhammadiyah”, Musãwa Jurnal Studi Gender dan Islam, vol. 11, no. 1 (2012), p. 135; Siti Ruhaini Dzuhayatin, Rezim Gender Mubammadiyab: Kontestasi Gender, Identitas dan Eksistensi (Yogyakarta: Suka Press Bekerjasama dengan Pustaka Pelajar, 2015). 
been characterized by, loving, the vastness in knowledge, independent in economic matters, and courage beyond conflictual cultural norms at that time. ${ }^{42}$

\section{Analysis of Case Inter-organizational Conflict on Work Ethics}

The second case presented here is organizational conflicts confronted by 'Aisyiyah when dealing with other women organizations in Yogyakarta in the 1950s to 1960s. 'Aisyiyah has been active members of the Coordinating Body of Women Organization (BKOW)-the local association of PPPI (Persyarikatan Perkoempoelan Perempuan Indonesia) formed during the first Women Congress in 1928, which later in 1946 became of Indonesian Women Congress (KOWANI). ${ }^{43}$ KOWANI embraces all kinds of women's organizations, regardless of their political, cultural, or religious affiliations, as well as their focus of services. ${ }^{44}$

'Aisyiyah experienced a number of tensions with an organization, which I call " $\mathrm{X}$ " organization here, in their organizational dealings. If the first case above showcases 'Aisyiyah intra-organizational conflicts, this second case presents example of inter-organizational conflicts encountered by "Aisyiyah. The "X" organization was among the most active women's organizations in the late 1950s to mid 1960s, when it was banned, allegedly due to the close affiliation with the Indonesian Communist Party. ${ }^{45}$ In this paper, I did not highlight the conflicting issues

42 Mitsuo Nakamura, "The Cultural and Religious Identity of Javanese Muslims: Problems of Conceptualization and Approach", Prisma, vol. 31 (1984), pp. 67-75; Nakamura, The Crescent Arises over the Banyan Tree; Siti Syamsiyatun, "Muslim Women's Politics in Advancing Their Gender Interests: A Case-Study of Nasyiatul Aisyiyah in Indonesia New Order Era”, Al-Jami'ah: Journal of Islamic Studies, vol. 45, no. 1 (2007), pp. 57-89; Ro’fah, “A Study of Aisyiyah”.

43 Blackburn, Kongres Perempuan Pertama.

44 S.E. Wieringa, "The Politicization of Gender Relations in Indonesia. The Indonesian Women's Movements and Gerwani until the New Order State", PhD. Dissertation (Amsterdam: University of Amsterdam, 1995); Suryochondro, Potret Pergerakan Wanita di Indonesia.

45 Saskia Wieringa, "The Birth of the New Order State in Indonesia: Sexual Politics and Nationalism”, Journal of Women's History, vol. 15, no. 1 (2003), pp. 70-91. Scholars have suggested that Indonesia's former president Suharto's New Order state legitimated itself by destroying the Partai Komunis Indonesia (Communist Party of 
experienced by 'Aisyiyah at the national headquarter, instead, I focus on their issues at local level in Yogyakarta. Two examples of organizational conflicts between "Aisyiyah and " $\mathrm{X}$ " organization with ethical loads are presented here: first is on deciding the timing of meeting or events, and second is methods of fund raising for local BKOW special events.

Mrs. Susiati and Mrs. Dalila, senior members of 'Aisyiyah informed me that in the Yogyakarta-based BKOW, 'Aisyiyah experienced conflicts mostly with the "X" organization. There were tensions in between their collaborations in the BKOW. Other women organizations seemed to subordinate to the command of the " $\mathrm{X}$ " organization and did not like to protest to avoid open confrontation. It was 'Aisyiyah who was usually brave enough to challenge it. Within BKOW in Yogyakarta at that time, the presidency of the organization was collegial, and entrusted to exofficial leaders of members organizations, with one after another was to take the lead, to preside the BKOW and its meetings. ${ }^{46}$

The conflicts began usually when the BKOW was presided by a representative of the "X" organization. The "Aisyiyah members reported that whenever the Leader of " $\mathrm{X}$ " organization presided over the BKOW meetings it used to propose and decide the meeting time in about the same with the time for Muslim's prayers. So, when 'Aisyiyah representatives took times out during the meeting because they needed to perform the prayers, the "X" organization representatives would point that 'Aisyiyah members were not discipline. When excused of being not discipline, 'Aisyiyah members would retort that because the president chose the meeting time coincide with the prayer time, and prayer to God is more important than the meeting, why couldn't the president choose the meeting time that could serve the interests of all member organizations. ${ }^{47}$

'Aisyiyah women were reported to protest the timing, and they also proposed a new time frame of the meeting which did not in conflict with prayer time. However, sometimes the chair did not approve. An example is narrated as follow:

"If the chair of the BKOW is from "X" organization, she would schedule the meeting in awkward time that usually in conflict with Muslim prayers

\footnotetext{
Indonesia, PKI).

46 Mrs. Susiati, interview (23 Mar 2005); Mrs. Delilah, interview (23 Mar 2005).

47 Mrs. Susiati, interview (23 Mar 2005); Mrs. Delilah, interview (23 Mar 2005).
} 
time, for instance from 5 to 7 PM. I did inform the forum that such time is in conflict with maghrib and isya' prayers. I asked 'is it possible to move forward the meeting time, for instance from 3:30 to 5:30 PM; what is the hazard of moving forward the meeting schedule? If it is agreeable then 'Aisyiyah representative will be fully participating in the meeting, otherwise, we will ask permission to leave the meeting to perform maghrib prayer", 48

Similar incidence was also told by other 'Aisyiyah informant, she told:

"if the BKOW meeting coincided with prayer time, I asked permission to leave the meeting for a while, because I need to do prayer, on time preferably. Often, I asked whether it is possible or not to find meeting schedules that serve better to all representatives' needs? If 'Aisyiyah representative had to preside the meeting in the BKOW, we always tried to cater to the need of others, and at the same time to avoid the meeting time coincides with prayer time. By doing such deliberation and a little negotiation, everyone is usually happy. Sometimes I just do not understand why the "X" organization often made awkward meeting schedule". 49

There were clearly some kind of competitions, besides cooperation, among these women organizations in the BKOW. In the case of the debate about timing for meeting, clearly "X" organization and 'Aisyiyah had different views, and preference, and either organization did not willing to give up. Consequently, they often debated with each other, and they attempted to have greater influence and receive respects from other members' organizations. ${ }^{50} \mathrm{I}$ argue that when " $\mathrm{X}$ " organization accused 'Aisyiyah members were not disciplined because they left the meeting to do their prayers, it was an effort from the " $\mathrm{X}$ " organization to downgrade 'Aisyiyah in the eyes of other members, and at the same time to capitalize "X" organization's social capital by showing of as being discipline. From the data gathered, I find that 'Aisyiyah and " $\mathrm{X}$ " organization had taken contending as a way of addressing the conflict of meeting time; both parties argued for their interests, took their own ways, and did not come to a fine resolution. As such result in tense relationship between the two

\footnotetext{
48 Mrs. Susiati, interview (23 Mar 2005).

49 Mrs. Delilah, interview (23 Mar 2005).

50 Ibid.
} 
organizations.

In few occasions, however, with silent support from other women's organizations 'Aisyiyah' proposal about meeting schedule was approved, the time was moved accordingly, because the " $\mathrm{X}$ " organization did not present good arguments. But such support came with negotiation, that when 'Aisyiyah women took a turn to preside the BKOW meeting they would consult the timing with other women organizations. 'Aisyiyah did not give up without knowing the argument, instead it questioned whether the timing can be changed or not, what are the arguments if it cannot be changed. If it can be changed that 'Aisyiyah proposed new timing that can serve their purposes without reducing others' right. I think in these conflict cases 'Aisyiyah has utilized not only contending strategy, but also negotiation strategy to solve the conflict, similar to the theory posed by McClain and Pruitt. ${ }^{51}$

The 'Aisyiyah informant also told other examples of organizational conflicts between 'Aisyiyah and " $\mathrm{X}$ " organization in the BKOW. It was a common practice during the 1950 s to 1960 s that women organizations collaborate to celebrate the Indonesian Independence Day, Women's Day, Kartini Day or other important dates together. For that purpose, they form temporary organizing committee consists of representatives of women organizations. Once, in a preparation for fund raising to organize a series of activities " $\mathrm{X}$ " organization proposed that they would sell lottery. The decision of approving the use of selling lottery for the fundraising was taken in a meeting when 'Aisyiyah representative was not in the meeting because she did the maghrib prayer. It was told that when this 'Aisyiyah came back re-joining the meeting she was informed that the decision had been made while she was away. ${ }^{52}$

The situation was certainly not favorable for 'Aisyiyah, religiouswise; the decision of selling lottery for the BKOW fundraising was in contradictory with 'Aisyiyah's view on business ethics. According to the belief of 'Aisyiyah, selling lottery is an unlawful business in Islam, so

51 Lindsay McClain, "The Art of Creative Conflict Resolution: A Critical Evaluation of Approaches to Post-Conflict Reconstruction in Northern Uganda", Pursuit - The Journal of Undergraduate Research at the University of Tennessee, vol. 1, no. 1 (2010); Pruitt, Rubin, and Kim, Social Conflict.

52 Mrs. Delilah, interview (23 Mar 2005).. 
'Aisyiyah had to respond accordingly. To proceed the response, 'Aisyiyah representative, Mrs. Delila, asked clarification, she recalled. She asked to the forum 'Can the decision of selling lottery for fundraising be revisited and revised?' The representatives from " $\mathrm{X}$ " organization said it cannot be, because it is already taken while 'Aisyiyah representatives were going outpraying. Furthermore, the president said to 'Aisyiyah representatives that it was important that they followed all the meeting diligently. The 'Aisyiyah representative did not want to do debate about conflicting time again and again. She posed a threat instead by saying:

"Alright, if the BKOW will continue to do fundraising by selling lottery to finance our activities, please go ahead, but please pardon us, 'Aisyiyah will not involve in this engagement. It is a matter of seriousness for us, because selling lottery is not the right way for fundraising in our view, it is haram (unlawful religiously). 'Aisyiyah do not want to find money by a haram way. However, if the decision can be revisited, we will propose other methods of fund raising that do not contradict with everyone belief, I am sure." 53

She told that after presenting her rejection to the proposal, and her statement about 'Aisyiyah's stand point she kept silent and looking at other representatives of women organizations. She considered that many of the women were anxious, she thought probably many of them did not agree with selling lottery, but they had no courage to protests. After much tensed silence, a representative of a women's organization raised her hand and asked to re-open the discussion, by arguing that if 'Aisyiyah did not want to involve in the activities then probably the activities would not be successful, because it was 'Aisyiyah which had most membership. Further, she proposed that they needed to hear 'Aisyiyah's proposal for fundraising. ${ }^{54}$

My informant told again that she responded if the decision can be changed, then 'Aisyiyah proposed that they could do fundraising by organizing a bazaar. In the bazaar all of members organization can do exhibition and sell their products; then a certain percentage of the profit be donated to the BKOW; and/or the BKOW created short courses in which participants pay modest fee, and the payment go to the
${ }^{53}$ Ibid.
${ }^{54}$ Ibid. 
BKOW. Leaders of women organization became the instructors, share their expertise to participants. At the end, after listening to 'Aisyiyah's explanations of their rejection to " $\mathrm{X}$ " organization's proposal of selling lottery, and much debate and discussion the BKOW could accept the changes. To make the long story short, 'Aisyiyah's proposal of doing bazaar for fundraising to the replace the selling of lottery was approved. The fundraising was done through the bazaars instead of selling lottery. ${ }^{55}$

In these inter-organizational conflicts 'Aisyiyah applied different strategies to address their conflicting interests with " $\mathrm{X}$ " organization. 'Aisyiyah clearly took different strategies in this case which seemed to have more impacts to social life than to their personal ones. Apart from negotiation, 'Aisyiyah also applied a strategy of threatening and argued with religious arguments. 'Aisyiyah posed a threat that they would not participate in any BKOW's events if the methods of fundraising contradict their religious business ethics. 'Aisyiyah women believe that selling lottery or gambling is not the right way for fundraising. 'Aisyiyah had been confident in posing the threat, because these women knew that most members and participants of the BKOW's activities in the area had been from 'Aisyiyah.

Despite showing a threat, however, 'Aisyiyah also proposed solution to fundraising, that is through bazaars and giving short courses. What had been proposed by 'Aisyiyah can actually be termed as transforming conflict into a new outcome that serve the interests of all parties, if we are using Lederach's theory on conflict transformation. ${ }^{56}$ These two activities were believed not in contradiction to any belief or ethics system adhered by all members of the BKOW. I think in this case 'Aisyiyah showed maturity by trying to embrace the interest of all members rather than putting forward its own interest and negating others'. The result was clear, all members approved 'Aisyiyah proposal. 'Aisyiyah seemed to be more relaxed with conflict of meeting schedule than the one deals of business ethics. In the former, 'Aisyiyah offered negotiation of the time schedule; which most time was agreed but other time were not successful. When it was unsuccessful, 'Aisyiyah did not take any specific action or if we use Pruitt's theory, it is called inaction and withdrawing.

\footnotetext{
55 Ibid.

56 Lederach, The Little Book of Conflict Transformation.
} 


\section{Current Organizational Culture in Responding to Conflicts}

Having presented conflictual cases encountered by 'Aisyiyah in the past, in this sub-section I discuss how current 'Aisyiyah women have inherited important virtues, strategies and skills in dealing with organizational discontents from former 'Aisyiyah activists, such as those analyzed previously. To illustrate this argument, I will summarize experiences of two young 'Aisyiyah women with feminist and inclusive points of view when they encounter conflicts or divergence of perspectives with elder members of 'Aisyiyah. The case is related to the revitalization of the spirit of 'Aisyiyah, whose name is taken from 'Aisyah, one of the beloved wives of Prophet Muhammad. In recent years with the rise of transnational, conservative Islamism in In donesia, ${ }^{57}$ there also emerges contending interpretation of the imagery of 'Aisyah, the wife of the Prophet. The new proposal comes from 'Aisyiyah members who are attracted to a more conservative interpretation of the attitudes and behavior of 'Aisyah. ${ }^{58}$ They argue that the wife of the Prophet was imagined to be more subdued and disenchanted with social and political affairs. It is observable that some local 'Aisyiyah women have been identified to promote such socially inactive womanhood. ${ }^{59}$

Various hermeneutics of the imagery of 'Aisyah with regard to feminist perspectives also create subtle tension within the organization. ${ }^{60}$ In addition to expected roles and behavior of 'Aisyiyah members to be more domestic-oriented as mentioned above, a national leader of 'Aisyiyah, Mrs. Amqia, confessed that the current structure of 'Aisyiyah with its long and heavy administrative lines does not conform to the expected feminist structure which prefers to be lean and flexible. As a feminist, she has wanted that 'Aisyiyah be more flexible in organizing

57 Lukman Hakim, "Conservative Islam Turn or Popular Islam? an Analysis of the Film Ayat-ayat Cinta”, Al-Jami'ab: Journal of Islamic Studies, vol. 48, no. 1 (2010), pp. 101-28.

58 Syamsiyatun, "Muslim Women's Politics in Advancing Their Gender Interests"; Rosnani Hashim, "Indonesian Islam in a New Era: How Women Negotiate Their Muslim Identities By Susan Blackburn, Bianca J. Smith, and Siti Syamsiyatun, eds.", American Journal of Islam and Society, vol. 26, no. 1 (2009), pp. 109-11.

59 Mrs. Rohani, interview (20 Nov 2019). Author's observation in a number of 'Aisyiyah religious learning (pengajian) and gatherings.

${ }^{60}$ Ibid.; Mrs. Amqia, interview (20 Sep 2020). 
things and be not too burdened with hierarchical, seniority, and departmental boxes. To address such intra-organizational conflicts, she adopts different strategies such as by accepting the reality of cognitive dissonance between her and other members, by utilizing her professional standing to cross-departmental ideas exchanges. Direct confrontation is usually avoided, she does not respond to rumors that contradict her actions, instead she would hold the formal decisions of the organization in matters or issues in which leaders and members of 'Aisyiyah are in conflicts or have no single understanding between one another. ${ }^{61}$

Avoiding violent confrontation, prioritizing islah and referring back to organizational regulation and formal decisions, as mentioned by Mrs. Amqia, in fact are parts of the virtues and principles upheld by 'Aisyiyah in responding to conflicts. Based on my interviews with current leaders of 'Aisyiyah, ${ }^{62}$ there are virtues and principles applied in contemporary 'Aisyiyah in response to disagreements, differing standpoints, or conflicts that affect the organization. I summarized the principles and virtues in addressing organizational conflicts shared by my informants above as follows.

First, when there is/are conflicts of interests, intra or interorganizational in nature, 'Aisyiyah women shall first refer to organizational regulations and official documents related to contested issues. These regulations are manifested in various forms, such as the Constitution of 'Aisyiyah (Anggaran Dasar dan Anggaran Rumah Tangga), Decree or decisions of Tanwir and Muktamar (two highest national meeting/congresses), and in official documents produced by 'Aisyiyah in response to certain issues. Pertaining to obligatory consultation to regulation, the leaders made clear statements that as such must also be adopted by administrators of 'Aisyiyah's amal usaba (religious-driven enterprises), such as hospitals, universities, schools, cooperative enterprises, orphanages, and others.

Second, the 'personality' and honor of 'Aisyiyah as an organization, must be held in the highest consideration; the interests of the organization are prioritized over the interests of individuals, who might

${ }^{61}$ Mrs. Amqia, interview (20 Sep 2020). member of current Central Board of 'Aisyiyah.

62 Mrs. Nordji, interview (10 Sep 2020); Mrs. Amqia, interview (20 Sep 2020); Mrs. Suswi, interview (27 Jan 2020); Mrs. Shomika, interview (27 Jan 2020). 
have different individual views. All 'Aisyiyah leaders in all levels must be firm in respecting and implementing the organizational principles in conflict resolution. They do not indulge themselves in unnecessary quarrels, non-substantive differences that will disgrace themselves and the organizations.

Third, 'Aisyiyah puts forward the strategy of deliberation, negotiation, and islah (fostering reconciliation, peace, harmony) in dealing with differences of opinion and conflicts. There is nothing like a Javanese term "pokoke kudu iki ..." (there is nothing, but like this) in the process; instead the women often use Javanese term, "kabeh isa dirembug" (all can be address with deliberation/negotiation).

Fourth, when criticizing other parties' programs, including the government's, Aisyiyah also suggests ways or proposals to improve it. The organization do not only just criticize for being unhappy, for example. This principle had been practiced, such as in cases analyzed in previous sub-sections. Fifth, 'Aisyiyah does not use 'unkind' methods, such as seizing and gnawing at solving problems. Several examples in conflicts of donated land (tanah wakaf) given to 'Aisyiyah on which the organization has built health centers and orphanages were taken back by the heirs of the donators, 'Aisyiyah continued to pursue negotiations and deliberations and avoided seizure strategy.

Sixth, in organizational conflicts that contain elements criminal matters, 'Aisyiyah would pursue the formal process to the competent authority of the state, as well as of the organization. 'Aisyiyah has team that specifically work on legal aid for the organization.

Seventh, the virtues of respecting humanity are kept highly; so 'Aisyiyah shall maintain a good relationship (silaturabim), keep in touch with those who are different, including those who are ideologically or religiously different.

\section{Concluding Remarks}

Indonesian Muslim women have been organizing since the early twentieth century, long before the birth of the Indonesian state in 1945. Women have been organizing for many reasons, but they all agree that by organizing they can achieve much more meaningful purposes than by acting individually. They all dream of better life for women, children 
in particular dan humanity in general. Some organizations focus their work on education, while others on economic empowerment and health improvement. While organizing, undoubtedly, they encountered various, constant conflicts within organization and inter-organizations. If we are starting with about 30 women organizations participating in the first Women Congress in December 1928, now we find only three organizations that still exist, they are 'Aisyiyah, Wanito Katholiek, and Wanito Taman Siswa. Why are most women organizations fading and dying? The current paper argues that ability to resolve conflicts became a significant factor that makes women's organizations thrive or perish.

Aisyiyah as one of the active participants of the first Women Congress showed better endurance and sustainability compared to other participating women's organizations. Since its establishment in 1917, it constantly caters to the interests of women and children, through various lines of works and models of services. Like all organizations, obviously 'Aisyiyah has encountered problems and conflicts intra and inter-organizations, throughout its historical presence. The question is why 'Aisyiyah has successfully maintained its existence while other organizations have fallen apart and vanished? Few answers from the perspective of conflict resolution and transformation theories, and islah theories are: first, 'Aisyiyah has the flexible ability to adapt to new environment and challenges; it is willing to evolve; such as in the case of changing the name. When the Java-centric name Sapa Tresna was no longer inspire and relevant to new members outside Java then the organization adopted a new name 'Aisyiyah. The new name was proven to be inspirational and beyond local, cultural borders.

Second is 'Aisyiyah ability to select various strategies to address organizational conflicts which they encounter on daily basis. My research showed that 'Aisyiyah has applied various strategies for resolving and transforming their organizational conflicts from in action to threat, and from contending to negotiation. In general, we can see that 'Aisyiyah has shown its preference for negotiation rather than confrontation in most of the conflicting cases I reviewed. When 'Aisyiyah rejected a plan proposed by other women's organization, such as in case number one, it not only explained the arguments 'Aisyiyah women have disproved, that is in this case of selling lottery for fundraising. 'Aisyiyah did not only 
reject the idea of selling lottery, but also showed a new way that might suit to all members and did not violate religious norms upheld by the concerned organizations, that is by proposing bazaar and donation of facilitators. It has the endurance to find ways yet with ever maintaining the relationships, even in the case with "X" organization with which 'Aisyiyah had frequent organizational conflicts.

From my research on 'Aisyiyah's strategy in responding to conflicts, I found also the leadership of 'Aisyiyah treasure the wisdom and experiences showed by former 'Aisyiyah activists, such as expressed by Mrs. Nordji, and Mrs. Amqia current leaders of 'Aisyiyah. Current 'Aisyiyah leadership have made clear that all 'Aisyiyah activists be equipped with basic virtues and skills for handling conflicting cases. The interests for the unity and sustainability of the organization are respected and are prioritized before the personal interests of members. Leaders of 'Aisyiyah at all levels are equipped with knowledge of organizational regulations and ethics, as shown in case number two and number three.

Lastly, I can conclude that willingness and ability to adapt to new situations and challenges, as well as resilience to find common interests from different agencies, intra and inter-organization have helped 'Aisyiyah to sustain. Additional ability to select and apply different strategies to address different problems and conflicts are also a key factor for an organization to endure that have been inherited from generation to the next. Without that minimum skills to address conflicts, an organization have greater chance to fall apart and perish. 


\section{BIBLOGRAPHY}

Abbott, Nabia, Aishah: the Beloved of Mohammed, North Stratford, NH: Ayer, 2000.

Aini, Kuratul, "Peranan Organisasi Wanita Taman Siswa dalam Pengembangan Pendidikan di Yogyakarta (1932 - 1946)", BA Thesis, Surakarta: Universitas Sebelas Maret, 2007.

Aryanti, Tutin, "Shame and Borders: The 'Aisyiyah's Struggle for Muslim Women's Education in Indonesia", in Gender, Religion and Education in a Chaotic Postmodern World, ed. by Zehavit Gross, Lynn Davies, and Al-Khansaa Diab, Dordrecht: Springer Netherlands, 2013, pp. 83-92 [https://doi.org/10.1007/978-94-007-5270-2_6].

Blackburn, Susan, Kongres Perempuan Pertama: Tinjauan Ulang, trans. by Koesalah Soebagyo Toer, Jakarta: Yayasan Obor Indonesia dan KITLV, 2007.

Chaudhry, Atif and Ch Asif, "Organizational Conflict and Conflict Management: a Synthesis of Literature", Journal of Business and Management Research, vol. 9, 2015, pp. 238-44.

Creswell, John W., Qualitative Inquiry \& Research Design: Choosing among Five Approaches, 4th edition, Los Angeles: SAGE, 2018.

Doorn-Harder, P.A. van, "Controlling the Body: Muslim Feminists Debating Women's Rights in Indonesia", Religion Compass, vol. 2, no. 6, Wiley, 2008, pp. 1021-43 [https://doi.org/10.1111/j.17498171.2008.00105.x].

Doorn-Harder, Pieternella van, Women Shaping Islam: Reading the Qu'ran in Indonesia, Urbana: University of Illinois Press, 2010.

Dzuhayatin, Siti Ruhaini, "Dinamika Ideologisasi Gender dalam Keputusan Resmi Muhammadiyah", Musãwa Jurnal Studi Gender dan Islam, vol. 11, no. 1, 2012, pp. 135-78 [https://doi.org/10.14421/ musawa.2012.111.135-178].

----, Rezim Gender Mubammadiyah: Kontestasi Gender, Identitas dan Eksistensi, Yogyakarta: Suka Press Bekerjasama dengan Pustaka Pelajar, 2015. Fikri, "Transformasi Nilai Al-Islah terhadap Keberagaman Konflik: Epistemologi Hukum Islam dalam Al-Qur'an”, Al-Risalah, vol. 
Siti Syamsiyatun

16, no. 02, 2018, pp. 201-16 [https://doi.org/10.30631/al-risalah. v16i02.308].

Hakim, Lukman, "Conservative Islam Turn or Popular Islam? an Analysis of the Film Ayat-ayat Cinta", Al-Jami'ah: Journal of Islamic Studies, vol. 48, no. 1, 2010, pp. 101-28 [https://doi.org/10.14421/ ajis.2010.481.101-128].

Hamdi, Saipul, "Politik Islah: Re-Negosiasi Islah, Konflik, dan Kekuasaan dalam Nahdlatul Wathan di Lombok Timur", Jurnal Kawistara, vol. 1, no. 1, 2011, pp. 1-14 [https://doi.org/10.22146/kawistara.3902].

Hashim, Rosnani, "Indonesian Islam in a New Era: How Women Negotiate Their Muslim Identities By Susan Blackburn, Bianca J. Smith, and Siti Syamsiyatun, eds.", American Journal of Islam and Society, vol. 26, no. 1, 2009, pp. 109-11 [https://doi.org/10.35632/ ajis.v26i1.1420].

Identitas, Visi, dan Misi 'Aisyiyah, http://www.aisyiyah.or.id/id/page/ identitas-visi-dan-misi.html, accessed 14 Feb 2020.

Lederach, John Paul, The Little Book of Conflict Transformation, Vancouver, B.C: Langara College, 2016.

Lubis, Dahlia, "Peran Muslimah dalam Penyelesaian Konflik", TEOSOFI: Jurnal Tasawuf dan Pemikiran Islam, vol. 5, no. 2, 2015, pp. 486-512 [https://doi.org/10.15642/teosofi.2015.5.2.486-512].

Mattl, Christine, "John Paul Lederach; The Little Book of Conflict Transformation", Perspektive Mediation, vol. 5, no. 4, 2008, p. 222.

McClain, Lindsay, "The Art of Creative Conflict Resolution: A Critical Evaluation of Approaches to Post-Conflict Reconstruction in Northern Uganda", Pursuit-The Journal of Undergraduate Research at the University of Tennessee, vol. 1, no. 1, 2010.

Moleong, Lexy J., Metodologi Penelitian Kualitatif, 38th edition, Bandung: PT Remaja Rosdakarya, 2018.

Muchtar, Darmiyanti, “The Rise of the Indonesian Women's Movement in the New Order State", Master Thesis, Murdoch: Murdoch University, 1999.

Nakamura, Mitsuo, “The Cultural and Religious Identity of Javanese Muslims: Problems of Conceptualization and Approach”, Prisma, 
vol. 31, 1984, pp. 67-75.

----, The Crescent Arises over the Banyan Tree: A Study of the Mubammadiyah Movement in a Central Javanese Town, c.1910s-2010, 2nd edition, Singapore: Institute of Southeast Asian Studies, 2012.

Nurmila, Nina, "The Indonesian Muslim Feminist Reinterpretation of Inheritance", in Islam in Indonesia: Contrasting Images and Interpretations, ed. by Jajat Burhanudin and Kees van Dijk, Amsterdam: Amsterdam University Press, 2013, pp. 109-22 [https://doi. org/10.1515/9789048516254-008].

Ocktaviana, Sentiela, Widjajanti M. Santoso, and Dwi Purwoko, "PeranPeran Perempuan di Wilayah Konflik: Antara Korban, Penyintas, dan Agen Perdamaian", Jurnal Masyarakat dan Budaya, vol. 16, no. 3, 2014, pp. 383-98 [https://doi.org/10.14203/jmb.v16i3.40].

Panggabean, Syamsu Rizal et al., Policing Religious Conflicts in Indonesia, trans. by Natalia Laskowska, Jakarta: Center for the Study of Religion and Democracy, Paramadina Foundation, 2015.

"Peran Perempuan dalam Penyelesaian Konflik Kurang Diakui", KOMPAS.com, 24 Mar 2010, https://nasional.kompas.com/ $\mathrm{read} / 2010 / 03 / 24 / 16383094 /$ Peran.Perempuan.dalam.Penyelesaian. Konflik.Kurang.Diakui..., accessed 10 Oct 2020.

"Pimpinan dan Amal Usaha Seluruh Indonesia", www.aisyiyah.or.id, http://www.aisyiyah.or.id/en/page/amal-usaha.html, accessed 11 Sep 2020.

PP 'Aisyiyah, Sejarah Pertumbuhan dan Perkembangan 'Aisyiyah, Yogyakarta: Pimpinan Pusat'Aisyiyah: Seksie Khusus Penerbitan dan Publikasi, 1992.

Pruitt, Dean, Communication Chains in Negotiation Between Organizations, Occasional Papers, no. 3, Istanbul: Sabanc1 Universitesi, 2003.

Pruitt, Dean G. and Douglas F. Johnson, "Mediation as an Aid to Face Saving in Negotiation", Journal of Personality and Social Psychology, vol. 14, no. 3, 1970, pp. 239-46 [https://doi.org/10.1037/h0028883].

Pruitt, Dean, Jeffrey Rubin, and Sung Hee Kim, Social Conflict: Escalation, Stalemate, and Settlement, 3rd edition, Boston: McGraw-Hill Education, 2003. 
Putra, Hannan, "Ensiklopedi Hukum Islam: Islah (1)", Republika Online, 23 Nov 2012, https://republika.co.id/berita/dunia-islam/ khazanah/12/11/23/mdxhpd-ensiklopedi-hukum-islam-islah-1, accessed 25 May 2020.

Putra, Muhammad Ghazali Bagus Ani, Perempuan-Perempuan Pemburu Surga: Menyibak Rahasia Kejayaan 'Aisyiyah, Yogyakarta: Suara Muhammadiyah, 2017.

Rahim, M. Afzalur, "Toward a Theory of Managing Organizational Conflict", International Journal of Conflict Management, vol. 13, no. 3, 2003, pp. 206-35 [https://doi.org/10.2139/ssrn.437684].

Ramadhini, Tika and David Kloos, "Visualizing Female Islamic Leadership in Indonesia: Suara 'Aisyiyah and Amanah", in Voyage of Discovery: Exploring the Collections of the Asian Library at Leiden University, ed. by Alexander Reeuwijk, Leiden: Leiden University Press, 2017.

Ro'fah, “A Study of 'Aisyiyah: An Indonesian Women's Organization (1917-1998)", Master Thesis, Montreal: McGill University, 2000.

Sejarah 'Aisyiyah, http://www.aisyiyah.or.id/id/page/sejarah.html, accessed 11 Sep 2020.

“Siapakah Pengusul Nama Organisasi 'Aisyiyah?”, IBTimes.ID, 27 Feb 2020, https://ibtimes.id/siapakah-pengusul-nama-organisasiaisyiyah/, accessed 28 Feb 2020.

Suryochondro, Sukanti, Organisasi-Organisasi Wanita di Indonesia, 1975.

----, Potret Pergerakan Wanita di Indonesia, Jakarta: Rajawali, 1984.

Suwardi, Anna Christi, "Peran Gerakan Perempuan dalam Reintegrasi Perempuan Eks-Kombatan Pasca Konflik: Studi Atas Liga Inong Aceh (LINA)", Jurnal Hubungan Internasional, vol. 4, no. 1, 2015, pp. 12-22 [https://doi.org/10.18196/hi.2015.0062.12-22].

Syamsiyatun, Siti, "A Daughter in the Indonesian Muhammadiyah: Nasyiatul Aisyiyah Negotiates a New Status and Image", Journal of Islamic Studies, vol. 18, no. 1, Oxford University Press, 2007, pp. 69-94.

----, "Muslim Women's Politics in Advancing Their Gender Interests: A Case-Study of Nasyiatul Aisyiyah in Indonesia New Order Era", Al-Jami'ah: Journal of Islamic Studies, vol. 45, no. 1, 2007, pp. 57-89 
[https://doi.org/10.14421/ajis.2007.451.57-89].

----, Serving Young Indonesian Muslim Women: the Dynamics of the Gender Discourse in Nasyiatul Aisyiyah 1965-2005, Saarbrücken: Lambert Academic Publsihing, 2010.

----, “Aisyiyah Women: The Messages of Sidang Tanwir", IBTimes.ID, 18 Nov 2019, https:/ /ibtimes.id/aisyiyah-women-the-messages-ofsidang-tanwir/, accessed 9 Sep 2020.

'Tentang | Majalah Suara 'Aisyiyah', Suara Aisyiyah, https://suaraaisyiyah. id/tentang/, accessed 11 Nov 2020.

Widati, Suryan, Iwan Triyuwono, and Eko Ganis Sukoharsono, "Wujud, Makna dan Akuntabilitas 'Amal Usaha' sebagai Aset Ekonomi Organisasi Religius Feminis", Jurnal Akuntansi Multiparadigma, vol. 2, no. 3, 2011, pp. 369-80 [https://doi.org/10.18202/ jamal.2011.12.7139].

Wieringa, Saskia, "IBU or the Beast: Gender Interests in Two Indonesian Women's Organizations”, Feminist Review, no. 41, 1992, pp. 98-113 [https://doi.org/10.2307/1395237].

----, "The Birth of the New Order State in Indonesia: Sexual Politics and Nationalism", Journal of Women's History, vol. 15, no. 1, 2003, pp. 70-91 [https://doi.org/10.1353/jowh.2003.0039].

---- "The Politicization of Gender Relations in Indonesia. The Indonesian Women's Movements and Gerwani until the New Order State", PhD. Dissertation, Amsterdam: University of Amsterdam, 1995. 
Siti Syamsiyatun 